\title{
The Use of Poster Sessions to Develop Professionalism, Domain Five of the Ecuadorian National English Teachers' Standards
}

\author{
María V. Morales J. ${ }^{1} \&$ María A. Morales J. ${ }^{2}$ \\ ${ }^{1}$ Post Graduate School, Universidad Casa Grande de Guayaquil, Guayaquil, Ecuador \\ ${ }^{2}$ Foreign Language Department, Universidad Estatal de Guayaquil, Guayaquil, Ecuador \\ Correspondence: María V. Morales J., Post Graduate School, Universidad Casa Grande de Guayaquil, Guayaquil, \\ Ecuador. Tel: 00-593-0994299195. E-mail: maria.morales@casagrande.edu.ec
}

\author{
Received: February 23, 2017 Accepted: May 26, 2017 Online Published: May 30, 2017 \\ doi: $10.5539 /$ elt.v10n7p 21 \\ URL: http://doi.org/10.5539/elt.v10n7p21
}

\begin{abstract}
This study describes the presence of professional skills found in poster session proposals in order to consider the use of poster sessions for developing the skills required by the 2012 Ecuadorian Standards for English teachers, specifically related to the fifth domain professionalism. Thirteen poster session proposals for a national English teacher conference were analyzed to identify professional skills using the International Teaching English to Speakers of Other Languages (TESOL) Conference rubric to describe their academic quality, and Halleck and Connor's Coding Scheme Checklist to describe the TESOL proposal genre characteristics. The results provided evidence of the skills related to the Ecuadorian national standards for English teachers as well as their academic strengths and weaknesses. The poster session can be an effective strategy to help teachers become more proactive and autonomous in growing professionally. This study can be useful for English teachers working to meet the national standards and institutions wanting to explore new strategies to develop and implement the English Teachers' Standards.
\end{abstract}

Keywords: poster session, professionalism, standards, active learning, proposal, rhetorical moves

\section{Introduction}

The widespread use of English in today's world is leading educational systems to analyze the level of this language proficiency in their countries. According to the EF English Proficiency Index (EF EPI) (Note 1), in 2016 Ecuador occupies the $47^{\text {th }}$ position among 72 countries, behind Latin American countries like Argentina, Chile and Peru, placing Ecuador among those with a low level of language proficiency (Education First, 2016). Ecuador just passed new policies, regulations and requirements for teachers in 2016; therefore, it is imperative to improve the quality of the teaching process and encourage the implementation of standards used for this purpose.

To improve programs, international educational organizations and systems have considered as necessary to implement the use of standards to guide improvements. TESOL International Association was the first to develop such international standards with its English as a Second Language (ESL) Standards for PRE-K-12 Students in 1997. According to Kuhlman and Staehr (2012), these standards are organized into five domains, that are Language, Culture, Instruction, Assessment and Professionalism; which was included as the fifth domain, as the intersection of all domains because it drives all that teachers of English do and who they are. As stated by TESOL (2016), the goals of Domain 5 Professionalism include the capacity of teachers to keep current with new instructional techniques, research results, advances in the English as a Second Language (ESL) field, education policy issues; demonstrate knowledge in the field and participate actively in professional growth opportunities.

In 2012, the Ecuadorian Ministry of Education established its own standards for English teachers (Ministerio de Educación del Ecuador, 2012), based on the TESOL standards. For Ecuador, to establish the standards is just a first step to improve English teaching in the country. The real challenge to meet the standards and specifically improve professionalism is to develop in teachers an understanding of the voluntary, autonomous nature of professionalism even after graduating from university as part of a personal professional growth plan aimed at bringing about change and enhancing learning in the classroom.

Even though the standards in Ecuador were passed in 2012, most of the teachers do not know about them or how to accomplish them. According to an interview done by the author of this study to seven English teachers in 
Guayaquil, in April 2016, most teachers related professionalism with the state of having a professional degree and having values; only one teacher mentioned the need to keep current as part of the professional profile (see Appendix B).

Most of the strategies used by teachers to improve professionalism are related to attending conferences/workshops, but this participation may be just passive learning and usually does not lead to change. However, a more active strategy to be used could be presenting at a poster session, which according to the TESOL organization, (2016) is "a visually explanatory exhibit of ideas or results presented in an attractive and interactive way allowing short, informal discussion between the presenter(s) and attendees, as attendees circulate within the poster-session area" (see Appendix A - Pictures 1-2). A poster session reflects the theory of active learning at its best, since it is self-directed learning, improves student learning, and represents learning by doing/sharing. A poster session selects presenters by reviewing proposals, which are a one page summary or academic essay to be presented in visually in a poster.

The purpose of this study was to describe the professional skills found in poster session proposals; and their genre characteristics, defined as rhetorical moves (Note 2) by Swales (1990). The proposals were part of a poster session presented at a Conference for English teachers in Guayaquil, Ecuador; organized by a local university. It took place from April $28^{\text {th }}$ to April $30^{\text {th }}, 2016$.

Several studies have explored the academic benefits of poster sessions such as the development of academic skills needed for research processes (Adkins, 2012), the use of reflection (Stewart, 2008), and the integration of theory and practice (McNamara, 2010), but no studies have looked at poster sessions as a strategy to encourage teachers to meet English Teachers Standards, specifically Domain 5, the development of professionalism, in the country.

Although, some universities in main cities such as Guayaquil, Quito and Loja have held poster sessions related to English Language Teaching, the results have not been published. According to SCImago Journal Rank (2015), which is a measure of scientific influence of scholarly journals that accounts for both the number of citations received by a journal and the importance or prestige of the journals where such citations originate; Ecuador published only four articles about language and linguistics in 2015.

\section{Literature Review}

Why should teachers or educational institutions use poster sessions? Poster sessions present an interesting and useful way of developing academic skills and sharing academic information, thus are gaining acceptance worldwide (Rowe, 2009). To present a poster, interested teachers need to elaborate a proposal which is a 300 -word academic essay summarizing the theory, aims, and support for their findings. The topic of the proposal is a classroom innovation or action research. The poster presenters are selected through a process of peer review.

Poster sessions first appeared in Europe as a logistical solution to a lack of time to present papers orally (Hess \& Brooks, 1988), and have steadily gained popularity in the United States since their first national appearance at the 1974 Biochemistry/Biophysics Meeting (Davis, 1992); (Maugh, 1974). Poster sessions are used at scientific meetings as a way to share scientific information with the public, motivate discussion, and inspire research (Hess, Tosney, \& Liegel, 2009). Additionally, poster sessions are being used to develop research and other professional skills, according to Vujakovic (1995); and Wimpfheimer (2004) whose studies concluded that elaborating a poster is an effective means of developing both research skills and creative abilities.

According to Richards (2010), one aspect of professionalism involves becoming familiar with the standards the profession sets and having a desire to attain those standards. Professionalism does not end when the teacher finishes an undergraduate or graduate program. English teachers are professionals when they are autonomous and responsible for maintaining professional standards.

According to the Ecuadorian English teacher standards (2012), evidence of professionalism is when teachers keep current with new instructional techniques, research results, advances in the English as a Foreign Language (EFL) field, and when teachers work collaboratively with school staff and the community to improve the learning environment, provide support, and advocate for students and their families.

Poster sessions, EFL standards and the theory of active learning have very much in common. To present in a poster session, teachers need the skills stated in the standards; the ability to read and conduct classroom research, demonstrate knowledge of language teaching methods; and at the same time, teachers are serving as professional resources in their educational communities. Teaching standards are related to the theory of active learning because the standards contained in the fifth domain, professionalism, imply that English teachers must stay current, innovate in the classroom, read and conduct research, collaborate with others and be efficient with their teaching practices. The theory of active learning, according to Collins and O'Brien, (2011) is the process of keeping 
students mentally, and often physically active in their learning through activities that involve them in gathering information, thinking, and problem solving. By elaborating a proposal, teachers are involved in authentic learning, because they need to show their own innovations or research, which is something real done by them as individual teachers or with a colleague. According to Michael (2006), "Learning involves the active construction of meaning by the learner" (p. 160).

Poster session proposal quality can be analyzed by identifying moves or functional components of proposals that are basically genre characteristics defined by Swales (1990) as rhetorical moves. Halleck \& Connor (2006) used genre analysis and the rhetorical moves developed by Swales to identify components of a successful TESOL proposal.

\section{Methodology}

This study describes the evidence in poster session proposals and posters of professional skills necessary to meet the national standards for English teachers. To describe the professional skills found, three instruments were used: the TESOL International Conference proposal rubric to evaluate proposals for professional academic skills, an adapted version of the rubric to evaluate the posters and Halleck and Connor's (2006) Rhetorical Moves Checklist to determine the presence or absence of TESOL proposal genre characteristics found in the one-page summaries of conference proposals.

\subsection{Participants}

To select the participants, there was a call for participation in which one hundred and ten in-service English teachers with academic degrees in teaching English as a foreign language were invited via email to present an innovation or research in a poster session within a local congress for English teachers. Eighty of the teachers invited belong to the Go teacher program which is an Ecuadorian government program that sent English teachers to the United States to improve their English language and teaching skills. Twenty teachers were students from two local universities who were finishing a Master's program for English teachers; and ten teachers were English teachers in a local university. It was inferred that all selected teachers have the B2 level of English proficiency since they belong to master's degree level. B2 indicates that teachers can interact comfortably in a professional environment even though they still lack vocabulary.

The invitation was also spread through a social network to recruit participants through a website designed to offer support for the poster session. The site, available at https://sites.google.com/site/posterproposalscongress2016/, contained information about proposals, examples of posters and proposals, the evaluation criteria, dates, and guidelines to follow. The website was used to receive the proposals. The site was available for one month and it registered 360 visits. Twenty participants confirmed their attendance to the workshop and just eight participants attended. In regard to the proposals sent, thirteen teachers sent proposals.

The peer reviewers were four English teachers with experience presenting in poster sessions and peer reviewing proposals. The 12 selected presenters were all English teachers with experience in English as a Foreign Language, five of them have master's degrees in Teaching English and seven were currently in the process of getting it. Two of the selected proposals were presented before at the TESOL Convention 2016. They were included to help conceptualize poster sessions.

\subsection{Instruments}

Table 1 shows the close relationship between standards, instruments and poster sessions (proposals and poster presentation). Though the study is reporting results for Domain 5, a poster session can also provide evidence of the skills found in the other four domains. 
Table 1. Relationship of national standards and the instruments to determine presence of professionalism

\begin{tabular}{|c|c|c|c|}
\hline \multirow{4}{*}{$\begin{array}{l}\text { Ecuadorian National } \\
\text { Standards } \\
\text { for English Teachers } \\
\text { (Based on TESOL Standards) }\end{array}$} & \multicolumn{2}{|c|}{$\begin{array}{l}\text { Evidence of national standards } \\
\text { Poster Session April } 2016\end{array}$} & \multirow{2}{*}{$\begin{array}{l}\text { Halleck and Connor } \\
\text { (2006) } \\
\text { Coding Scheme } \\
\text { Checklist }\end{array}$} \\
\hline & $\begin{array}{l}\text { PROPOSAL } \\
\text { RUBRIC }\end{array}$ & $\begin{array}{l}\text { PRESENTATION } \\
\text { RUBRIC }\end{array}$ & \\
\hline & $\begin{array}{l}\text { (based on TESOL } \\
\text { rubric) }\end{array}$ & $\begin{array}{l}\text { (adapted from TESOL } \\
\text { rubric) }\end{array}$ & $\begin{array}{l}\text { For analysis of } \\
\text { rhetorical marks typical } \\
\text { of academic writing }\end{array}$ \\
\hline & & & $\begin{array}{l}\text { found in TESOL } \\
\text { proposals }\end{array}$ \\
\hline $\begin{array}{l}\text { 1. Language } \\
\text { Standard } 1 \\
\text { 1a3. Teachers demonstrate } \\
\text { knowledge of the rhetorical } \\
\text { and discourse structure as } \\
\text { applied to the English } \\
\text { language. }\end{array}$ & $\begin{array}{l}\text { Written language is } \\
\text { clear. }\end{array}$ & Spoken language is clear. &  \\
\hline
\end{tabular}

\section{Culture}

\begin{tabular}{lllll}
\hline 3. Curriculum Development & $\begin{array}{l}\text { Topic related to Topic related to methods } \\
\text { methods }\end{array}$ & $\begin{array}{l}\text { Means 1, Means 2 } \\
\text { (Methods) }\end{array}$ \\
\hline
\end{tabular}

\begin{tabular}{ll}
\hline 4. Assessment & Self-assessment of Reflection answering \\
& teaching with rubric questions \\
& when writing \\
& proposal (reflection)
\end{tabular}

\section{Professionalism}

\section{Standard 5}

5a. Teachers demonstrate knowledge of history, research, educational public policy, and current practice in the field of EFL teaching and apply this knowledge to inform teaching and learning.

5b. Teachers take advantage of professional growth opportunities and demonstrate the ability to build partnerships with colleagues and students' families, serve as community resources, and advocate for students.

\section{Topic is current}

Focused/appropriate

Based on theory

Supported

evidence

Clear
Previous research, gap, goal, outcomes, benefits, importance, competence claim of author
Teachers
take Teachers take advantage
advantage of of professional growth professional growth opportunities serve as opportunities, serve community resources.
as community Interaction opens resources.
possibilities for collaboration.

Proposals and posters were analyzed using the data collected through two rubrics: A Proposal Rubric and a Poster Rubric (both adapted from TESOL, 2013, see Appendix C-D); to identify the presence of skills related to the national standards. A checklist based on the Halleck and Connor code scheme (Table 2) was used to analyze presence of genre characteristics.

The Proposal Rubric is a standard rubric used to analyze and select poster proposals for presentation at the annual 
international TESOL Convention. The objective of using this rubric was to determine not only the selected proposals, but to analyze the academic quality of proposals and posters. This rubric consists of five criteria: topic, purpose, theory, support and clarity of the poster proposal. Each of the five criterion has a maximum value of five, giving a maximum score of 25. Proposals were accepted with scores ranging from 17 to 25 or a minimum of $70 \%$ of the highest score. The criterion, Topic, measures the teachers' ability to stay current with relevant or significant themes related to the field. The second criterion, Purpose, shows the teachers' ability to determine the objectives or outcomes that they want visitors to take away from their poster presentation. The third criterion, Theory, measures the connection between theory, practice or research and the content of the presentation. The fourth criterion, Support, measures how well the conclusions or recommendations were substantiated and finally, the last criterion, Clarity, measures the clarity of the proposal. The results were used to determine areas that needed to be developed or improved in order to help teachers meet the standards.

The Poster Rubric measured the quality of the poster presentation. The rubric considered the same five criteria, with minor changes related to the visual presentation of the content, due to the importance of catching the visitors' attention as well as presenting visually the results in a clear, logical manner. The posters were evaluated during the third and last day of the poster session by three reviewers who were professional educators attending the Congress. One was an international English teacher trainer and the other two were English program coordinators from local universities.

A Checklist based on The Coding Scheme for Conference Proposal Analysis developed by Halleck and Connor's (2006), was used to describe the presence of TESOL proposal genre characteristics identifying the rhetorical writing structures. The coding scheme was used to identify the existence and number of particular rhetorical moves of the proposals to determine the academic quality. Rhetorical moves are genre characteristics and refer to Territory (context), Reporting Previous Research, Gap, Goal, Means 1 (methods), Means 2, Outcomes, Benefits, Importance, and Competence Claim (proposer's credibility). (Halleck \& Connor, 2006). See Table 2 for definitions of categories to identify the existence and number of particular genre characteristics. Results from the analysis of proposals and posters identified strengths and weaknesses including rhetorical structures.

Table 2. Coding scheme for conference proposal analysis (Halleck and Connor's, 2006)

\begin{tabular}{|c|c|}
\hline Category & Operationalization \\
\hline $\begin{array}{l}\text { Territory } \\
\text { Reporting }\end{array}$ & Establishes physical and/or situational context of the activity \\
\hline $\begin{array}{l}\text { previous research } \\
\text { (RPR) }\end{array}$ & Makes references to previous work, situating the current activity \\
\hline Gap & $\begin{array}{l}\text { In relation to theoretical or empirical territory, shows a lack of knowledge } \\
\text { in the field; serves to motivate the study }\end{array}$ \\
\hline Goal & States the aim and/or objective of the activity \\
\hline Means 1 & $\begin{array}{l}\text { Specifies the methodology, procedures, plans of action, and tasks of the } \\
\text { project }\end{array}$ \\
\hline Means 2 & $\begin{array}{l}\text { Specifies the presentation's method and procedure-what is to be } \\
\text { accomplished in a specified amount of time }\end{array}$ \\
\hline Outcomes & Presents findings or achievements resulting from the study \\
\hline Benefits & $\begin{array}{l}\text { Explains and connects outcomes (intended/projected) to real world } \\
\text { applications }\end{array}$ \\
\hline Importance claim & States the urgent need for the proposed activity \\
\hline $\begin{array}{l}\text { Competence } \\
\text { claim }\end{array}$ & States the proposer's credibility \\
\hline
\end{tabular}

Given its focus on proposals submitted to the TESOL Convention, the present study adopted the Halleck and Conner coding scheme to identify the presence of these moves in the selected proposals from this study and determine the strengths and weaknesses of the academic writing in order to make recommendations for the future.

\section{Poster Session}

The study had two phases: Phase 1, Call for Proposals and Phase 2 the implementation of the poster session. Phase 1 , included the process for selecting proposals through a website designed for the purpose, which 
presented the call for proposals and information about how to elaborate a poster proposal. There was also an optional workshop on how to elaborate proposals for interested teachers who wanted to participate.

Thirteen teachers sent their proposals. Eight of the thirteen teachers who sent their proposals belong to the group who attended the workshop; the other five did not attend the workshop; and from these five, two of them were teachers who had presented posters at previous conventions.

In Phase 2, there was the presentation of the 12 selected posters within the Congress for English Teachers and their evaluation using the poster presentation evaluation rubric. The posters were mounted on a 4-foot-by-8-foot display wooden board that includes the session title, and the participant's name. The posters were exhibited within the session for one hour all three days of the Congress.

\section{Results}

The results are evidence of the professional skills and genre characteristics found during the Conference.

\subsection{Evidence of professional skills}

Academic research and presentation skills - Proposals were analyzed using the TESOL rubric for proposals, which measured their academic quality. The maximum possible score was 25 and the minimum score for a proposal to be accepted was $17(68 \%)$. The academic quality of proposals and poster presentations, showed a slight difference. According to Figure 1, the average score for the proposals received was $74 \%$ and the average score for posters was $79 \%$, which shows a slight difference.

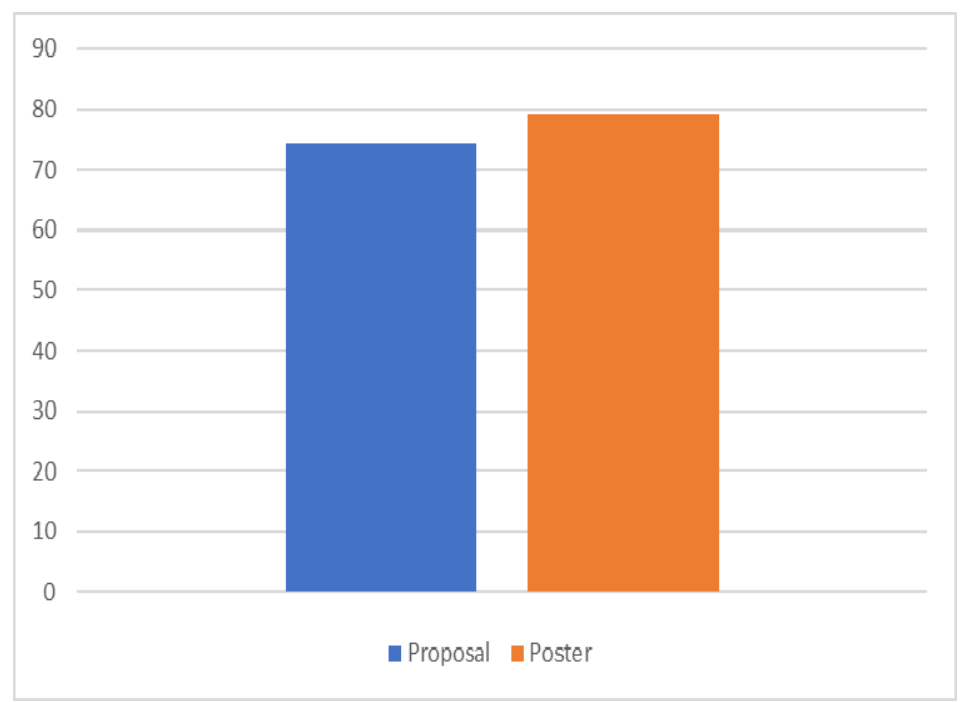

Figure 1. Proposal and poster average scores

When comparing the individual scores (See Figure 2) the scores indicate a considerable improvement between the proposal and poster presentation for three presenters, a moderate improvement for four presenters and a decrease for three presenters. Two accepted proposals were unable to present with posters. Proposal \#12 was evaluated but not presented as a poster and proposal \#13 was evaluated but not presented as a poster. 


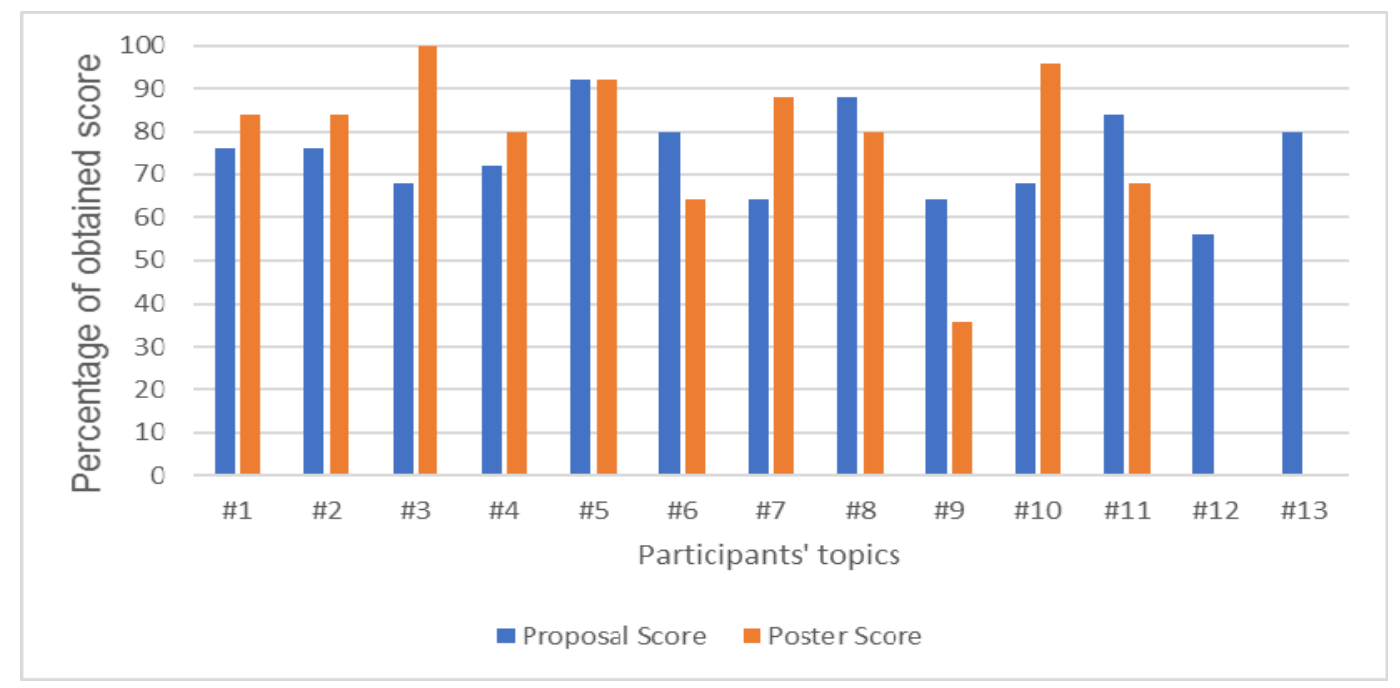

Figure 2. Comparison individual scores of proposals and posters

Comparing the results of the proposal and poster on Table 3, helps identify strengths and weaknesses where teachers need to improve.

Table 3. Proposals and posters scores by criteria

\begin{tabular}{lll}
\hline & Proposal & Poster \\
\hline Topic & $85 \%$ & $97 \%$ \\
Purpose & $78 \%$ & $84 \%$ \\
Theory & $64,6 \%$ & $76,2 \%$ \\
Support & $63 \%$ & $74,4 \%$ \\
Clarity & $69 \%$ & $74 \%$ \\
\hline
\end{tabular}

Table 3 indicates that for the criterion Topic, the posters received the highest score of $4.85(97 \%)$ and the proposals $4.36(85 \%)$. That score indicates that the topics were judged to be current. The criterion Purpose obtained the second best score with proposals receiving $3.92(78 \%)$ and posters $4.18(84 \%)$. This refers to evidence of focusing objectives and participant outcomes. The proposals obtained $3.46(69 \%)$ for Clarity and the posters $3.72(74 \%)$. This means that both the proposals and posters needed to be clearer regarding the written and visual presentation of the content. The criteria Theory and Support were better understood in the poster presentation than in the written proposal, which showed that theory and support are criteria that teachers need to work on in order to relate and base their work on theories. The proposals obtained 3,23 (64,6\%) for Theory and the posters 3,81 (76,2\%), while Support criterion obtained 3,15 (63\%) in proposal and 3,72 (74,4\%) in posters.

\subsection{Evidence of Genre Characteristics}

The proposals were examined to identify the existence and number of particular genre characteristics or rhetorical moves of the proposals using the coding scheme from Halleck and Connor (2006). Figure 3 shows the results of the identified rhetorical moves as evidence of understanding genre characteristics. 


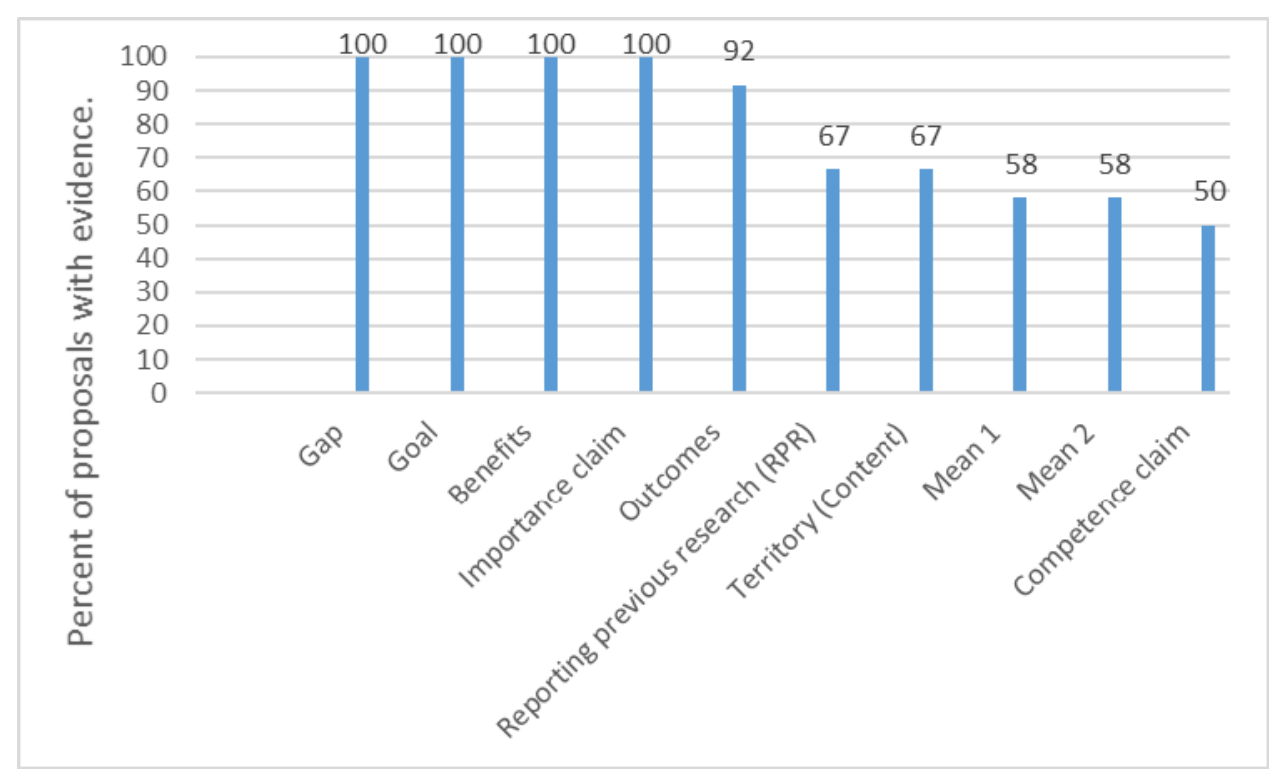

Figure 3. Percent of proposals with evidence of moves

The rhetorical moves Gap, Goal, and Benefits were found in all the proposals ( $\mathrm{n}=12,100 \%)$, whereas, Territory and Reporting Previous Research were found in $67 \%$ of the proposals, the moves Mean 1 and Mean 2, which are related to methods, procedures, plan of actions that lead to the goal and the procedure to carry out the actual presentation, were found in $58 \%$ of the proposals, Outcomes were found in $92 \%$; and the move Importance Claim was found in $50 \%$.

The average number of moves found per proposal was eight out of ten $(80 \%)$, see Appendix E. The majority of the rhetorical moves fell under four types: Gap, Goal, Benefits, and Importance Claim ( $\mathrm{n}=12,100 \%)$. N indicates the frequency of the move in the proposals; Outcomes was very frequent $(n=11 ; 92 \%)$, followed by Reporting Previous Research and Territory $(\mathrm{n}=8 ; 67 \%)$; Mean 1 and Mean $2(\mathrm{n}=7 ; 58 \%)$ and finally Competence Claims $(\mathrm{n}=$ 6; 50\%).

Proposal overall results for academic performance using the Proposal Rubric showed a score of 18,6 (74\%); while the results obtained through the identification of genre characteristics, which also measures academic performance, showed an average of $80 \%$ regarding the presence of the moves per proposal mentioned by Halleck and Connor.

When analyzing the topics in Table 4, there are three identified categories: assessment and curriculum, teaching strategies and using technology.

Table 4. Proposal topics

\begin{tabular}{|l|c|c|c|}
\hline \multicolumn{1}{|c|}{ PROPOSAL TOPICS } & \multicolumn{2}{c|}{ TOPIC CATEGORIES } \\
\cline { 2 - 4 } & $\begin{array}{c}\text { Assessment and } \\
\text { Curriculum }\end{array}$ & $\begin{array}{c}\text { Teaching } \\
\text { Strategies }\end{array}$ & $\begin{array}{c}\text { Using } \\
\text { technology }\end{array}$ \\
\hline $\begin{array}{l}\text { 1.- Rubrics as Authentic Assessment Tools Enhancing } \\
\text { Writing and Speaking Skills }\end{array}$ & & \\
\hline $\begin{array}{l}\text { 2.- Augmented Reality applied as a learning strategy on } \\
\text { ESL learners }\end{array}$ & & & \\
\hline 3.- Self-Assessment of Oral Skills using Mobile Devices & & $\mathrm{X}$ \\
\hline $\begin{array}{l}\text { 4.- Basic English enriched with professional tasks } \\
\text { improve professional communication }\end{array}$ & & $\mathrm{X}$ & \\
\hline $\begin{array}{l}\text { 5.-Literature Circles Motivate English Interaction in A1 } \\
\text { University Students }\end{array}$ & & $\mathrm{X}$ \\
\hline
\end{tabular}




\begin{tabular}{|l|l|l|}
$\begin{array}{l}\text { 6.- Using Authentic Online Materials to Improve B1 Level } \\
\text { Listening Proficiency }\end{array}$ & $\mathrm{X}$ & \\
\hline $\begin{array}{l}\text { 7.- Graphic organizers as cognitive strategies to promote } \\
\text { independent EFL learners }\end{array}$ & X & \\
\hline $\begin{array}{l}\text { 8.- Implementing Performance-Based Tasks as } \\
\text { Summative Evaluations in EFL Classrooms }\end{array}$ & $\mathrm{X}$ \\
\hline $\begin{array}{l}\text { 9.- Trailers In Facebook: An Authentic Material To } \\
\text { Motivate EFL Learning. }\end{array}$ & $\mathrm{X}$ & \\
\hline $\begin{array}{l}\text { 10.- Closing Comprehension Gaps Using Literature } \\
\text { Circles: From Classics to Blockbusters }\end{array}$ & $\mathrm{X}$ & \\
\hline $\begin{array}{l}\text { 11.- Professional Tasks Enrich Basic English for } \\
\text { University Students }\end{array}$ & $\mathrm{X}$ & \\
\hline $\begin{array}{l}\text { 12.- Teaching through English: documenting experiences } \\
\text { and sharing. }\end{array}$ & $\mathrm{X}$ & \\
\hline $\begin{array}{l}\text { 13.- Sustainability of National Standards through } \\
\text { Peer-to-Peer Training }\end{array}$ &
\end{tabular}

Fifteen percent of the topics were related to the category Assessment and Curriculum, while $54 \%$ to Teaching Strategies and $31 \%$ to the use of technology.

\section{Discussion}

The evidence of professional skills of the national English standards found in poster session proposals of this study includes the finding of the presence of genre characteristics of proposals. The genre characteristics called Goal or Objective was the one found in all the proposals of this study. This finding is similar to what Halleck \& Connor (2006) found in their study, where the goal or objective of the proposal was the most frequently found genre characteristic when they were identifying specific genre characteristics of a succesful proposal.

Results of this study show that Support, Theory and Clarity are the elements of proposals that teachers need to improve. This is important information to guide the improvements of the teachers' skills required by the national English standards, particularly to demonstrate ability to read and conduct classroom research.

The proposals of this study present findings which can be considered evidence-based teaching which is necessary to reflect on and improve instruction and assessment practices according to domain fifth of the national English standards. According to Michael (2006) this evidence should be used to guide teacher's decision making about how to best help students learn.

This sort of teacher reflection on practice is evidence of teacher's active learning, which according to Collins \& O'Brien (2011), is the process of keeping participants mentally, and often physically active in their learning through activities that involve them in gathering information, thinking, and problem solving.

According to national English teachers' standards, professionalism is present when teachers keep current with methods and knowledge. Findings in this study showed low presence of methods, procedures that lead to the goal of the proposals and procedures to carry out the presentation of results (mean 1 and mean $2=58 \%$ ) in the proposals. Richards (2002) mentions that professionalism does not end when the teacher finishes an undergraduate or graduate program. Poster sessions give teachers the opportunity to continue learning about methods and how to implement them.

Timing is one of the limitations of this study since the call for proposals for the poster session process was carried out in three months during students' vacation time and teachers did not have time to carry out formal projects in their classrooms. They did not have time to intentionally connect theory and practice except by reflecting on past experiences. Teachers wanting to present posters should have at least a year in advance to carry out classroom innovations and research. Another limitation, may be the lack of information on guidance on writing proposals.

For future poster sessions, it is recommended to include all teachers with a degree in teaching, not just teachers with master's degrees, in order to motivate all teachers' participation. 


\section{Conclusion}

Can poster sessions help English teachers to meet national standards? Yes, because they truly develop the professional skills. English teachers are not autonomous now, and poster sessions promote autonomy. According to Richards (2010), English teachers are professionals when they are autonomous and responsible for maintaining professional standards.

In order to write a poster proposal, teachers need to connect theory to practice, provide evidence of innovation and research; and express ideas clearly in English. This study found such evidence through the use of different qualities of academic communication skills such as 1) rhetorical moves that refer to the presence or absence of the genre characteristics found in the one-page summary of TESOL conference proposal and (2) academic research and presentation skills that TESOL looks for in proposals based on their rubric.

Poster Sessions should be used in professional development programs to guide the implementation of national English standards. Proposals can tell the teachers' areas of strengths and weaknesses. In the results found in this study, the teachers' strengths identified in the proposals were related to the description of the benefits of their study, objectives, the reason that motivated the study and the importance of the claim. The areas to improve were the omission of previous research and context; the methods used to collect data and the low credibility of claims or results presented in the proposals. Besides this, poster sessions give teachers the opportunity to share their findings with other colleagues and educational community.

Since teachers have to meet the standards, universities and institutions need to help English teachers to reach them. The implementation of a poster session within educational institutions can be a useful strategy to help teachers identify skills they need to develop, and can be done through the promotion of academic events such as university conferences. Perhaps the Ministry of Education can include poster sessions in their programs for professional development to help teachers identify characteristics of the proposal genre and improve academic research and presentation skills. According to Halleck and Connor (2006), being able to identify and reproduce genre characteristics helps future presenters "attend to aspects of form, content and audience".

Future research should include participants' perspectives about presenting and writing a proposal and understanding the participant experiences when writing a proposal. Additionally, it would be interesting to analyze what universities or educational institutions are doing to help teachers meet the national standards.

\section{References}

Adkins, D. R. (2012). Promoting Research to the Masses: Assessing the Impact of a Poster Walk. International Journal for the Scholarship of Teaching and Learning No. 2, Article 19., 6(2) July. https://doi.org/10.20429/ijsotl.2012.060219

Collins, J., \& O Brien, N. (2011). The Greenwood Dictionary of Education (2nd ed.). Greenwood Press. Retrieved 2016, from http://www.abc-clio.com/ABC-CLIOCorporate/product.aspx?pc=B3909C

Davis, M. (1992). Journal of Natural Resources and Life Sciences Education. Effective communication with poster displays, 21(2), 156-160.

Education First. (2016). EF-EPI The world's largest ranking of countries by English skills. Retrieved 2016, from http://www.ef.edu/epi/downloads/

Halleck, G., \& Connor, U. (2006). Rhetorical moves in TESOL conference proposals. Journal of English for Academic Purposes, 70-86. https://doi.org/10.1016/j.jeap.2005.08.001

Hess, G., \& Brooks, E. (1988). The class poster conference as a teaching tool. Journal of Natural Resources and Life Sciences Education, 27, 155-158.

Hess, G., Tosney, K., \& Liegel, L. (2009, July). Creating effective poster presentations. Medical Teacher, 31(4), 319-321. https://doi.org/10.1080/01421590902825131

Kuhlman, N., \& Staehr, D. (2012). Preparing effective teachers of English language learners: Practical applications for the TESOL P-12 Professional Teaching Standards. Alexandria: TESOL International Association.

Maugh, T. (1974, June). Poster Sessions: A New Look at Scientific Meetings. Science, 184(4144), 1361. https://doi.org/10.1126/science.184.4144.1361

McNamara, J. (2010). Using poster presentations as assessment of work integrated learning. Australian Collaborative Education Network National Conference. 
Michael, J. (2006). Where's the evidence that active learning works. Advances in Physicology Education, 30(4), 159-167. https://doi.org/10.1152/advan.00053.2006

Ministerio de Educación del Ecuador. (2012). English Teacher Standards. Retrieved 2016, from http://educacion.gob.ec/wp-content/uploads/downloads/2013/03/estandares_2012_ingles.pdf

Richards, J. (2010). Competence and performance in language teaching. RELC journal, 41, 101-122. https://doi.org/10.1177/0033688210372953

Richards, J. C. (2002). Methodology in language teaching: An Anthology of current practice. Cambridge university press. https://doi.org/10.1017/cbo9780511667190

Rowe, N. (2009). What impact do posters have on academic knowledge transfer? BMC Medical Education.

SCImago. (2015). SCImago Journal and country rank. Retrieved 2016, from $\mathrm{http}: / /$ www.scimagojr.com/countrysearch.php?country=ec\&area=1200

Swales, J. M. (1990). Genre analysis: English in academic and research settings. New York: Cambridge University Press. https://doi.org/10.1186/1472-6920-9-71

TESOL International Association. (2016). The TESOL Guidelines For Developing EFL Professional Teaching Standards. Obtenido de TESOL International Association: http://www.tesol.org/advance-the-field/standards/guidelines-developing-efl-professional-teaching-standards

Vujakovic, P. (1995). Making Posters. Journal of Geography In Higher Education, 19(2), 251-256. https://doi.org/10.1080/03098269508709313

Wimpfheimer, T. (2004, December). Peer-Evaluated Poster Sessions: An Alternative Method to Grading General Chemistry Laboratory Work. Journal of chemical education, 81(12), 1775. https://doi.org/10.1021/ed081p1775

\section{Notes}

Note 1. The EF English Proficiency Index (EF EPI) is a report which attempts to rank countries by the average level of English language skills amongst adults. It is the product of EF Education First, a global language training company, and draws its conclusions from data collected via English tests available for free over the internet.

Note 2. The study of genres in terms of rhetorical moves was originally developed by [John M.] Swales (1981, 1990, and 2004) to functionally describe a part or section of Research Articles. This approach, which seeks to operationalize a text into particular segments, originated from the educational objective of supporting the teaching of academic writing and reading for non-native speakers of English. 


\section{Appendix A}

\section{Pictures of the Poster Session}

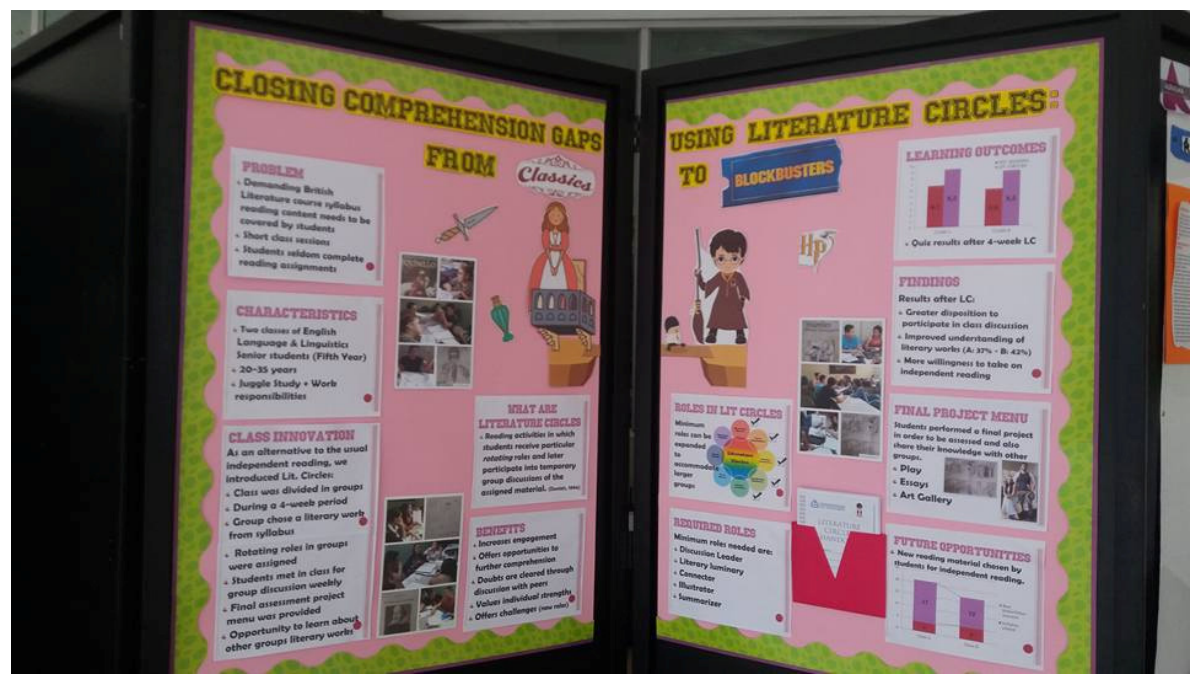

Appendix A - Picture 1

Participant's poster presented at the III Congress for English teachers organized by Universidad Católica de Guayaquil

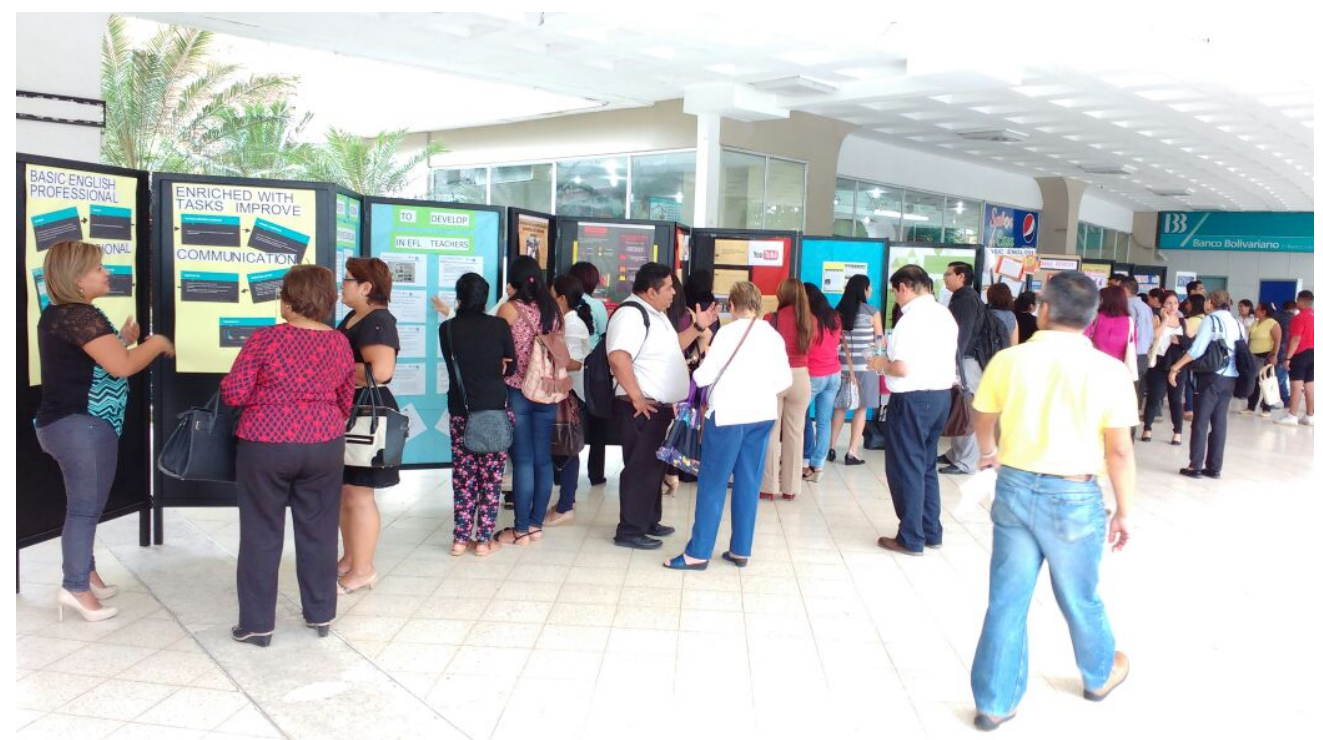

Appendix A - Picture 2

Poster Session at the III Congress for English teachers organized by Universidad Católica de Guayaquil

\section{Appendix B}

Categorization of Responses to interview about Professionalism

Sorting: organizing excerpts of interview according to concepts and categories

1.- When you hear the word professionalism, what comes into your mind?

\begin{tabular}{|l|l|}
\hline $\begin{array}{l}\text { BROAD CATEGORY } \\
\text { PROFESIONALISM } \\
\text { PERCEPTIONS }\end{array}$ & $\begin{array}{l}\text { PARTICIPANTS' RESPONSES (taken from teachers' written } \\
\text { answers) }\end{array}$ \\
\hline
\end{tabular}




\begin{tabular}{|l|l|}
\hline Responsibility and other values & $\begin{array}{l}\text { - In my personal opinion, it is about commitment, responsability } \\
\text { values } \\
\text { - I believe professionalism is a person who is organized in the job, } \\
\text { - Have a knowledge about values and is interested in do the best. } \\
\text { - to be capable to do his /her work in a right way } \\
\text { - a person who perform his or her job with integrity in all aspects } \\
\text { - Professionalism is to do a job according to its rules and ethics and } \\
\text { the commitment that it deserves. } \\
\text { - To work using good methods in order to achieve goals in a class. To } \\
\text { have success with inclusive students. To improve knowledge, } \\
\text { experiences and Skills with a magister degree. } \\
\text { - I believe professionalism is a person who is organized in the job, } \\
\text { have a knowledge about values and is interested in do the best. } \\
\text { - Knowledge, Be Confident, to have Courtesy, to be honest , and } \\
\text { Self-Improvement. } \\
\text {-Have professional competences in a field. } \\
\text {-Be updated in new teaching techniques } \\
- \text { Something that you have studied to be. Example: I studied } \\
\text { journalism so that I can work at any media as a journalist. }\end{array}$ \\
\end{tabular}

\section{2.- Do you see yourself as a professional? Why or Why not?}

\section{BROAD CATEGORY}

- SELF VIEW AS PROFESSIONAL

\section{Continue learning}

- Of course. I am a professional. However, you never stop learning especially a teacher. We all have the mission to be updated and well-informed about educative and politics issues.

-Yes, because I try to keep current

- Yes. I work with responsibility, ethic, values and using the methodology and techniques that I have already learnt in UK. Additionally I am capable to continue learning and get the objectives that I want you have in my life. One of them is to become a Minister.

- I think that I need to develop much more my skills.

-Yes, I do. I work on getting the standard competences to be a good professional

-yes. because all my life i have worked with responsability I like to be on time in my job, and I enjoy learning everyday new techniques to 




3.- Have you established professional goals, accomplished them and then realized there were benefits because of that achievement? Or nothing changed?

BROAD CATEGORY

- REACTIONS TO PROFESSIONAL GOALS

\section{Positive changes}

- It depends on your perspective. For instance, once I decided to make my students increase the communicative skills such as speaking and writing. First, you know the real level by diagnostic. The statistics reveals the reality. Then, I applied some strategies in class to improve them and finally, I compared and noticed that tool had perfectly worked so I felt very happy because I could achieve the academic goal.

- Yes. I stablished profesional goals. I studied abroad in the Go Teacher Program to work in a Public Institution to share muy knowledge and applied them with my students all that I learnt. Now I am in the process to get a permanent job. So my life changed for better. And I want to continue training and gaining experience to do my best at work.

- Yes, of course, I continue working on those. I have realized those goals had good influence in my performance.

-Yes, of course, every time I meet a goal I feel I've done an achievement.

- yes. I have had the opportunity about improve my skills in the English teaching, and I have the opportunity of traveling to USA where i could learn more about culture.

-Yes, and of course when you established your own and factible goals and you accomplish them, finally you are going to get benefits.

-Yes, I have, in fact, many of them have given to me a lot of benefits, 
and there were things changed but even though I need more.

-yes, evero scholar period is a challenge in some cases $\mathrm{i}$ accomplish what i planned

-Yes, i have, my only professional goals is to improve my English and get a mastery, although it is difficult for my situation, to get a certificate B2, because i passed all the time, without any kind of practice.

-Yes, I always establish my professional goals then I check and reflect them about my achievements.

\section{Benefits}

4.- In your experience, do teachers talk about being professionals or get together to plan what are they going to do to continue learning ?

\section{BROAD CATEGORY}

\section{- TEACHERS ACTIONS TOWARDS PROFESSIONALISM}

\begin{tabular}{|c|c|}
\hline Getting a higher degree & $\begin{array}{l}\text { To be honest, few teachers get together to plan or discuss topics about } \\
\text { how to improve the academic level of students. Just two or three do it, } \\
\text { but I think it is rewardable because you will see the good results at the } \\
\text { end of the term. } \\
\text { Yes. Some teathers gathered to talk about Universities offering } \\
\text { Magisters in English programs that we can participate. But firstable } \\
\text { de have to get the B2 level in order to get in a program. So we are } \\
\text { going to have some workshop to get that. }\end{array}$ \\
\hline $\begin{array}{l}\text { Getting the required proficiency } \\
\text { level }\end{array}$ & $\begin{array}{l}\text { Not all the time. the discussion topic is related to students progress } \\
\text { not about professionalism. } \\
\text { Teachers plan to continue learning because the goverment has } \\
\text { stablished a high level of English knowledge such as get the level B2 } \\
\text { with the purpose of get a best quality of education. } \\
\text { Plan what to do } \\
\text { In my experience, English teachers mainly work for an income. } \\
\text { Nothing else. } \\
\text { yes, they do, there are teachers very interested to be professionals but } \\
\text { there are others groups think that it is unnecesary to make an effort. } \\
\text { there are few teachers, the ones who are new in the public field that } \\
\text { think about it } \\
\text { Nowadays, the majority of the teachers, only have time for planning } \\
\text { or continuing learning. } \\
\text { Everyday, I learn something new and I love reflecting about it. }\end{array}$ \\
\hline
\end{tabular}

\section{5.- What has helped you to get positive results in your teaching}

practice? 


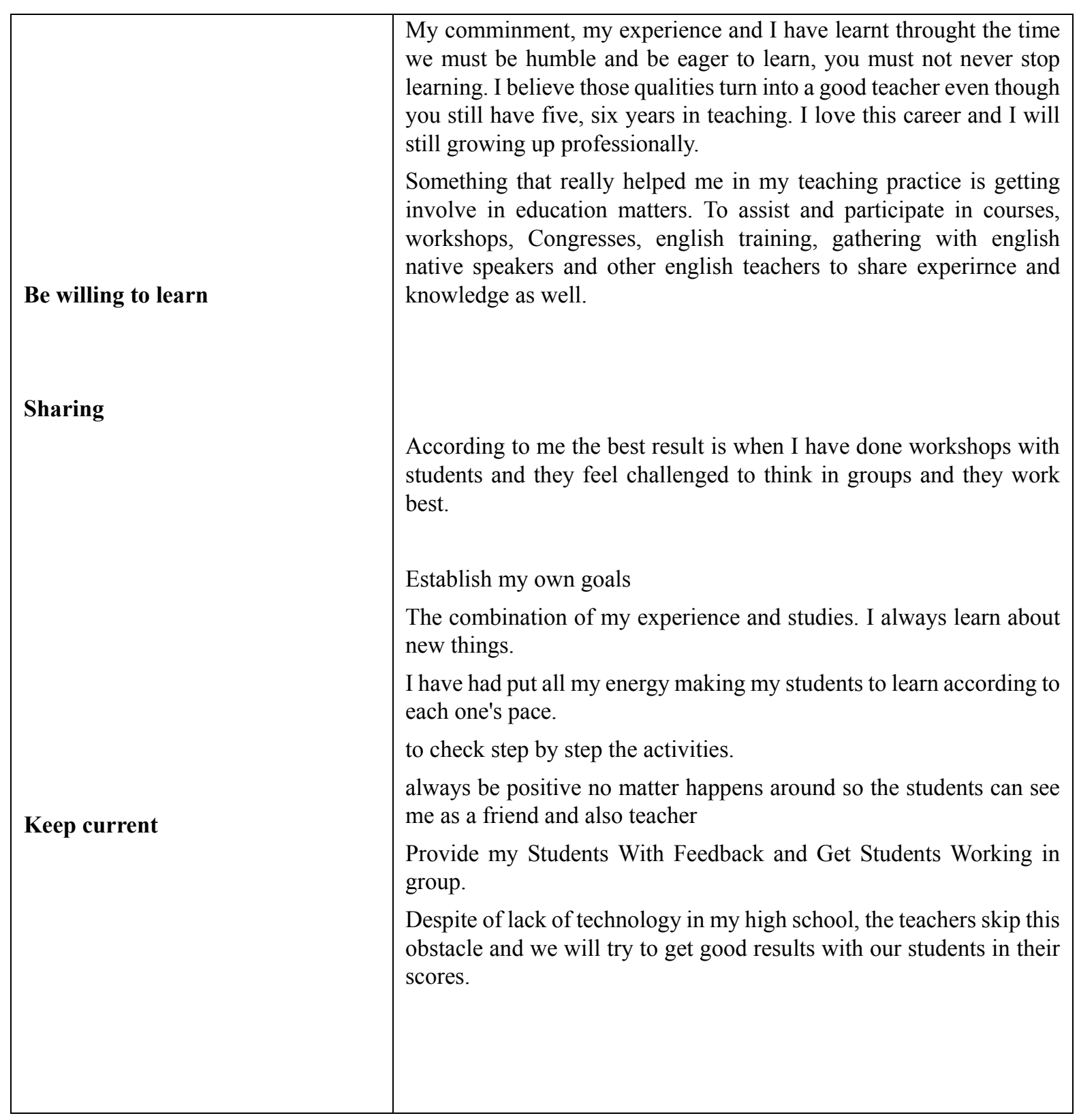

\section{6.- What do you think teachers need in order to develop professionalism?}

\section{BROAD CATEGORY}

- TEACHERS BELIEVES TO IMPROVE PROFESSIONALISM

-They first must love what they really do. As far as I am concerned, many people can be a teacher but only few of them give their best and feel the professionalism. I think that going to seminars, workshops could be helpful to improve your teaching style.

-In my opinion we teachers need more courses, workshop, congress, English training. In order to prepare us to get the B2 level and continue to achieve the magíster degree and as consequence we 


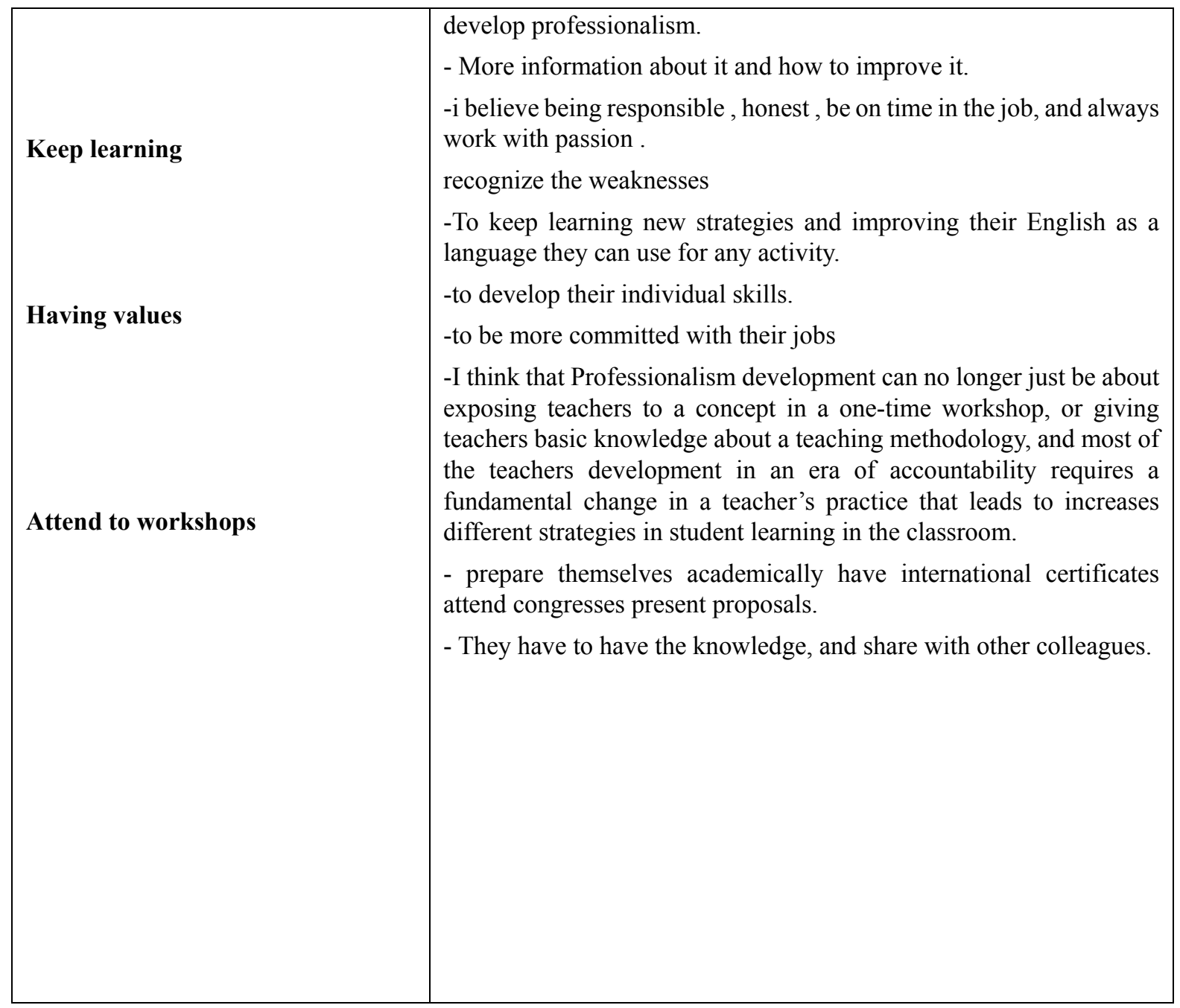

7.- Have you attended a Poster Session? If affirmative, which presentation can you recall from the Poster Session?

\section{BROAD CATEGORY}

- KNOWING ABOUT POSTER SESSIONS

\begin{tabular}{|l|l|}
\hline Know what poster sessions are & $\begin{array}{l}\text { Yes, I went two years ago to the Catholic Univesity Seminar in } \\
\text { 2014. I am sorry but I do not remember the name of the } \\
\text { presentation but I remember it was good and I could attend again } \\
\text { this year 2016. }\end{array}$ \\
$\begin{array}{l}\text { Not knowing what poster } \\
\text { sessions }\end{array}$ & $\begin{array}{l}\text { No, I think I do not. I do not remember a Poster Session But I am } \\
\text { interesting to attend it. } \\
\text { No. } \\
\text { no. } \\
\text { No I haven't } \\
\text { No, I haven't. }\end{array}$ \\
\hline
\end{tabular}




\begin{tabular}{|l|l|}
\hline & $\begin{array}{l}\text { no, I haven 't. } \\
\text { no, i would like to know what it is about } \\
\text { No, i haven't attended a poster Session. } \\
\text { Yes, I have. How to motivate students to read. }\end{array}$ \\
\end{tabular}

\section{Appendix C}

Proposal Evaluation Rubric (taken from TESOL 2013 Call for Proposals)

\begin{tabular}{|c|c|c|c|c|c|}
\hline $\begin{array}{l}\text { Evaluation } \\
\text { criteria }\end{array}$ & $\begin{array}{l}\text { Poor } \\
1 \text { point }\end{array}$ & $\begin{array}{l}\text { Fair } \\
2 \text { points }\end{array}$ & $\begin{array}{l}\text { Good } \\
3 \text { points }\end{array}$ & $\begin{array}{l}\text { Very Good } \\
4 \text { points }\end{array}$ & $\begin{array}{l}\text { Excellent } \\
5 \text { points }\end{array}$ \\
\hline $\begin{array}{l}\text { 1. Topic is } \\
\text { current and } \\
\text { relevant }\end{array}$ & $\begin{array}{l}\text { The topic is not } \\
\text { current, and/or } \\
\text { lacks importance or } \\
\text { appropriateness to } \\
\text { the field. It does not } \\
\text { appear to be a } \\
\text { worthwhile session. }\end{array}$ & $\begin{array}{l}\text { The topic is only } \\
\text { tangentially related to } \\
\text { the field, not } \\
\text { completely current or } \\
\text { important to the field } \\
\text { and/or to the potential } \\
\text { audience. It may not } \\
\text { be a worthwhile } \\
\text { session. }\end{array}$ & $\begin{array}{l}\text { The topic may not be } \\
\text { completely current or } \\
\text { groundbreaking, but } \\
\text { it is relevant to the } \\
\text { field and potential } \\
\text { audience. It might be } \\
\text { a worthwhile session. }\end{array}$ & $\begin{array}{l}\text { The topic is current, } \\
\text { important, and } \\
\text { appropriate to the } \\
\text { field and potential } \\
\text { audience. It appears } \\
\text { to be a worthwhile } \\
\text { session. }\end{array}$ & $\begin{array}{l}\text { The topic is cutting } \\
\text { edge, relevant, } \\
\text { ground-breaking, or } \\
\text { significant to the field } \\
\text { and potential } \\
\text { audience. It appears } \\
\text { to be a very } \\
\text { worthwhile session }\end{array}$ \\
\hline $\begin{array}{l}\text { 2. Purpose, } \\
\text { participant } \\
\text { outcomes, } \\
\text { and session } \\
\text { type }\end{array}$ & $\begin{array}{l}\text { The proposal is } \\
\text { inappropriate for } \\
\text { the session type, } \\
\text { and/or the } \\
\text { objectives are not } \\
\text { clearly stated or } \\
\text { implied }\end{array}$ & $\begin{array}{l}\text { The proposal may be } \\
\text { appropriate for the } \\
\text { session type. The } \\
\text { objectives and } \\
\text { participant outcomes } \\
\text { may be too general or } \\
\text { broad to be } \\
\text { achievable. }\end{array}$ & $\begin{array}{l}\text { The proposal is } \\
\text { Generally appropriate } \\
\text { for the session type. } \\
\text { The objectives and } \\
\text { participant outcomes } \\
\text { are stated or implied } \\
\text { but may lack } \\
\text { sufficient focus. }\end{array}$ & $\begin{array}{l}\text { The proposal is } \\
\text { appropriate for the } \\
\text { session type. The } \\
\text { objectives and } \\
\text { participant } \\
\text { outcomes are clear. }\end{array}$ & $\begin{array}{l}\text { The proposal matches } \\
\text { the session type. The } \\
\text { objectives and } \\
\text { participant outcomes } \\
\text { are very clear. }\end{array}$ \\
\hline $\begin{array}{l}3 \text {. Theory, } \\
\text { practice, } \\
\text { and/or } \\
\text { research } \\
\text { basis }\end{array}$ & $\begin{array}{l}\text { The proposal does } \\
\text { not mention theory, } \\
\text { practice, or } \\
\text { research, or it is } \\
\text { unclear how this } \\
\text { session } \\
\text { connected to the } \\
\text { field. }\end{array}$ & $\begin{array}{l}\text { The proposal } \\
\text { provides } \\
\text { background } \\
\text { references to } \\
\text { theory, practice, } \\
\text { and/or research, but it } \\
\text { is not specific, or it } \\
\text { does not relate the } \\
\text { theory, practice, } \\
\text { and/or research to the } \\
\text { content of the } \\
\text { presentation }\end{array}$ & $\begin{array}{l}\text { The proposal refers } \\
\text { somewhat to the } \\
\text { theory, practice, } \\
\text { and/or research on } \\
\text { which the } \\
\text { presentation is based } \\
\text { in an understandable } \\
\text { way and relates it to } \\
\text { the content of the } \\
\text { presentation. }\end{array}$ & $\begin{array}{l}\text { The proposal refers } \\
\text { clearly to the } \\
\text { theory, } \\
\text { practice, and/or } \\
\text { research on which } \\
\text { the presentation is } \\
\text { based in a thorough } \\
\text { and comprehensible } \\
\text { manner and relates } \\
\text { it directly to the } \\
\text { presentation }\end{array}$ & $\begin{array}{l}\text { The proposal refers } \\
\text { specifically to the } \\
\text { appropriate theory, } \\
\text { practice, and/or } \\
\text { research on which the } \\
\text { presentation is based } \\
\text { in a detailed, } \\
\text { thorough, and } \\
\text { comprehensible } \\
\text { manner and relates it }\end{array}$ \\
\hline
\end{tabular}




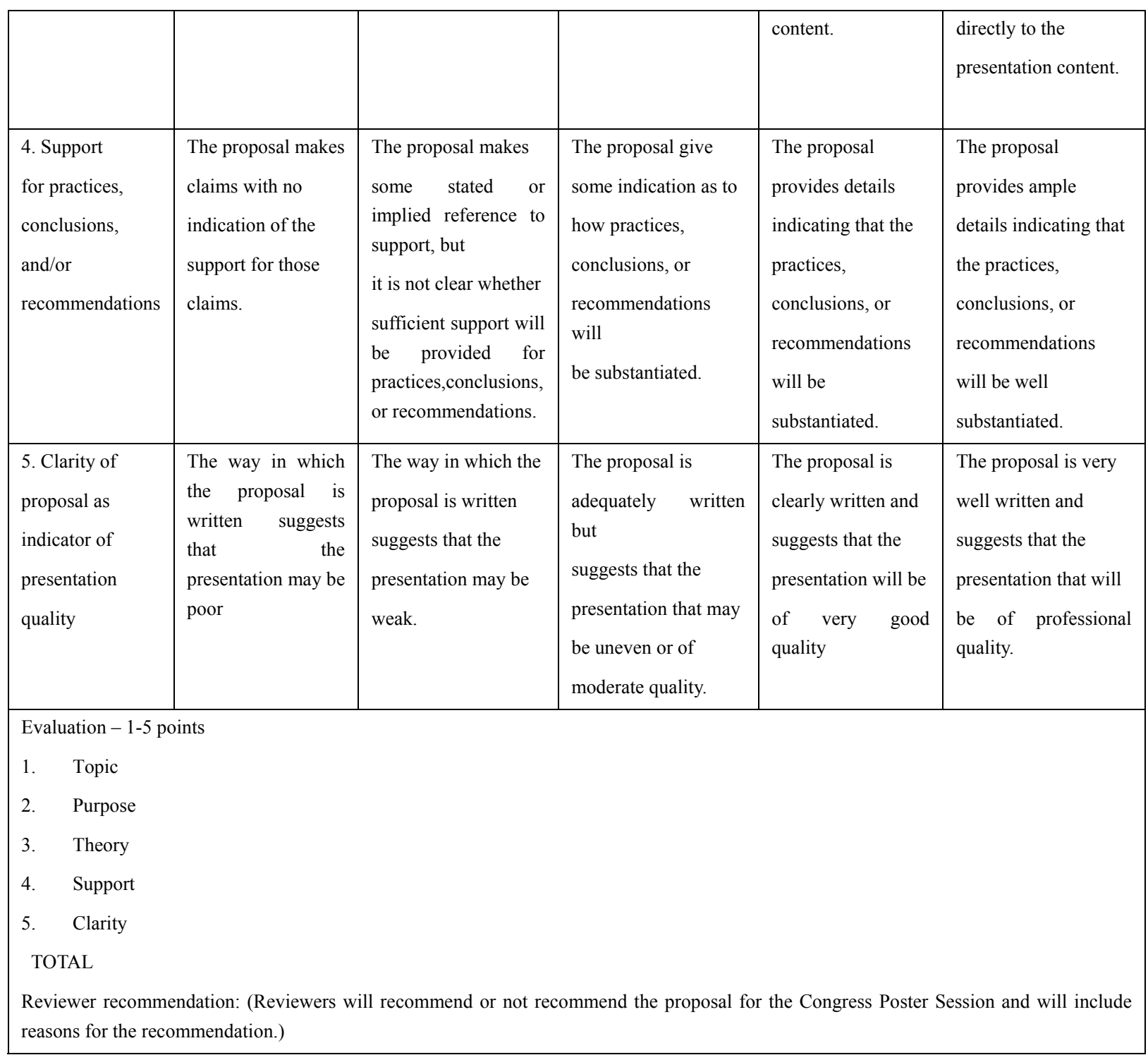

\section{Appendix D}

Poster Evaluation Rubric (Taken and adapted from TESOL 2013 Call for Proposals)

\begin{tabular}{|c|c|c|c|c|c|}
\hline $\begin{array}{l}\text { Evaluation } \\
\text { criteria }\end{array}$ & $\begin{array}{l}\text { Poor } \\
1 \text { point }\end{array}$ & $\begin{array}{l}\text { Fair } \\
2 \text { points }\end{array}$ & $\begin{array}{l}\text { Good } \\
3 \text { points }\end{array}$ & $\begin{array}{l}\text { Very Good } \\
4 \text { points }\end{array}$ & $\begin{array}{l}\text { Excellent } \\
5 \text { points }\end{array}$ \\
\hline $\begin{array}{l}\text { 1. Topic is } \\
\text { current and } \\
\text { relevant }\end{array}$ & $\begin{array}{l}\text { The topic is not } \\
\text { current, and/or } \\
\text { lacks importance or } \\
\text { appropriateness to } \\
\text { the field. It is not a } \\
\text { worthwhile poster. }\end{array}$ & $\begin{array}{l}\text { The topic is only } \\
\text { tangentially related to } \\
\text { the field, not } \\
\text { completely current or } \\
\text { important to the field } \\
\text { and/or to the potential } \\
\text { audience. }\end{array}$ & $\begin{array}{l}\text { The topic may not be } \\
\text { completely current or } \\
\text { groundbreaking, but } \\
\text { it is relevant to the } \\
\text { field and potential } \\
\text { audience. It is a } \\
\text { worthwhile poster. }\end{array}$ & $\begin{array}{l}\text { The topic is current, } \\
\text { important, and } \\
\text { appropriate to the } \\
\text { field and potential } \\
\text { audience. It is } \\
\text { a worthwhile } \\
\text { poster. }\end{array}$ & $\begin{array}{l}\text { The topic is cutting } \\
\text { edge, relevant, } \\
\text { ground-breaking, or } \\
\text { significant to the field } \\
\text { and potential } \\
\text { audience. It is a very } \\
\text { worthwhile poster. }\end{array}$ \\
\hline $\begin{array}{l}\text { 2. Purpose, } \\
\text { participant } \\
\text { outcomes, }\end{array}$ & $\begin{array}{l}\text { The poster is } \\
\text { inappropriate for } \\
\text { the session type, } \\
\text { and/or the }\end{array}$ & $\begin{array}{l}\text { The poster is } \\
\text { appropriate for the } \\
\text { session type. The }\end{array}$ & $\begin{array}{l}\text { The poster is } \\
\text { generally appropriate } \\
\text { for the session type. }\end{array}$ & $\begin{array}{l}\text { The poster is } \\
\text { appropriate for the } \\
\text { session type. The }\end{array}$ & $\begin{array}{l}\text { The poster matches } \\
\text { the session type. The } \\
\text { objectives and } \\
\text { participant outcomes }\end{array}$ \\
\hline
\end{tabular}




\begin{tabular}{|c|c|c|c|c|c|}
\hline $\begin{array}{l}\text { and session } \\
\text { type }\end{array}$ & $\begin{array}{l}\text { objectives are not } \\
\text { clearly stated or } \\
\text { implied }\end{array}$ & $\begin{array}{l}\text { objectives and } \\
\text { participant outcomes } \\
\text { are too general or } \\
\text { broad to be } \\
\text { achievable. }\end{array}$ & $\begin{array}{l}\text { The objectives and } \\
\text { participant outcomes } \\
\text { are stated or implied } \\
\text { but may lack } \\
\text { sufficient focus. }\end{array}$ & $\begin{array}{l}\text { objectives and } \\
\text { participant } \\
\text { outcomes are clear. }\end{array}$ & are very clear. \\
\hline $\begin{array}{l}\text { 3. Theory, } \\
\text { practice, } \\
\text { and/or } \\
\text { research } \\
\text { basis }\end{array}$ & $\begin{array}{l}\text { The poster does not } \\
\text { mention theory, } \\
\text { practice, or } \\
\text { research, or it is } \\
\text { unclear how this } \\
\text { session } \\
\text { connected to the } \\
\text { field. }\end{array}$ & $\begin{array}{l}\text { The poster provides } \\
\text { background } \\
\text { references to } \\
\text { theory, practice, } \\
\text { and/or research, but it } \\
\text { is not specific, or it } \\
\text { does not relate the } \\
\text { theory, practice, } \\
\text { and/or research to the } \\
\text { content of the } \\
\text { presentation }\end{array}$ & $\begin{array}{l}\text { The poster refers } \\
\text { somewhat to the } \\
\text { theory, practice, } \\
\text { and/or research on } \\
\text { which the } \\
\text { presentation is based } \\
\text { in an understandable } \\
\text { way and relates it to } \\
\text { the content of the } \\
\text { presentation. }\end{array}$ & $\begin{array}{l}\text { The poster refers } \\
\text { clearly to the } \\
\text { theory, } \\
\text { practice, and/or } \\
\text { research on which } \\
\text { the presentation is } \\
\text { based in a thorough } \\
\text { and comprehensible } \\
\text { manner and relates } \\
\text { it directly to the } \\
\text { presentation } \\
\text { content. }\end{array}$ & $\begin{array}{l}\text { The poster refers } \\
\text { specifically to the } \\
\text { appropriate theory, } \\
\text { practice, and/or } \\
\text { research on which the } \\
\text { presentation is based } \\
\text { in a detailed, } \\
\text { thorough, and } \\
\text { comprehensible } \\
\text { manner and relates it } \\
\text { directly to the } \\
\text { presentation content. }\end{array}$ \\
\hline $\begin{array}{l}\text { 4. Support } \\
\text { for practices, } \\
\text { conclusions, } \\
\text { and/or } \\
\text { recommendations }\end{array}$ & $\begin{array}{l}\text { The poster makes } \\
\text { claims with no } \\
\text { indication of the } \\
\text { support for those } \\
\text { claims. }\end{array}$ & $\begin{array}{l}\text { The poster makes } \\
\text { some stated or } \\
\text { implied reference to } \\
\text { support for } \\
\text { practices,conclusions, } \\
\text { or recommendations. }\end{array}$ & $\begin{array}{l}\text { The poster give } \\
\text { some indication as to } \\
\text { how practices, } \\
\text { conclusions, or } \\
\text { recommendations are } \\
\text { substantiated. }\end{array}$ & $\begin{array}{l}\text { The poster } \\
\text { provides details } \\
\text { apporting that the } \\
\text { practices, } \\
\text { conclusions, or } \\
\text { recommendations. }\end{array}$ & $\begin{array}{l}\text { The poster } \\
\text { provides ample } \\
\text { details indicating how } \\
\text { the practices, } \\
\text { conclusions, or } \\
\text { recommendations } \\
\text { are } \\
\text { substantiated. }\end{array}$ \\
\hline $\begin{array}{l}\text { 5. Clarity of } \\
\text { poster as } \\
\text { indicator of } \\
\text { presentation } \\
\text { quality }\end{array}$ & $\begin{array}{l}\text { The way in which } \\
\text { the poster is written } \\
\text { makes it difficult to } \\
\text { understand. }\end{array}$ & $\begin{array}{l}\text { The way in which the } \\
\text { poster is written } \\
\text { makes some parts } \\
\text { difficult } \\
\text { understand. }\end{array}$ & $\begin{array}{l}\text { The poster is } \\
\text { adequately presented. }\end{array}$ & $\begin{array}{l}\text { The poster is } \\
\text { clearly written and } \\
\text { easy to follow. }\end{array}$ & $\begin{array}{l}\text { The poster is very } \\
\text { well written and } \\
\text { is professional. }\end{array}$ \\
\hline \multicolumn{6}{|c|}{ Evaluation - 1-5 points } \\
\hline
\end{tabular}




\section{Appendix E}

\section{Comparison of Poster Proposal Results (P1) and Poster Presentation Results (P2)}

\begin{tabular}{|c|c|c|c|c|c|c|c|c|c|c|c|c|}
\hline \multirow[b]{3}{*}{ PROPOSALS } & \multicolumn{12}{|c|}{$\begin{array}{l}\text { RUBRIC INDICATORS } \\
\text { P1 : Poster Proposal Results } \\
\text { P2: Poster Presentation Results }\end{array}$} \\
\hline & \multicolumn{2}{|c|}{$\begin{array}{l}\text { TOPIC } \\
\text { SCORE }\end{array}$} & \multicolumn{2}{|c|}{$\begin{array}{l}\text { PURPOSE } \\
\text { SCORE }\end{array}$} & \multicolumn{2}{|c|}{$\begin{array}{l}\text { THEORY } \\
\text { SCORE }\end{array}$} & \multicolumn{2}{|c|}{$\begin{array}{l}\text { SUPPORT } \\
\text { SCORE }\end{array}$} & \multicolumn{2}{|c|}{$\begin{array}{l}\text { CLARITY } \\
\text { SCORE }\end{array}$} & \multicolumn{2}{|c|}{$\begin{array}{l}\text { TOTAL } \\
\text { SCORES }\end{array}$} \\
\hline & P1 & P2 & P1 & P2 & P1 & $\mathbf{P 2}$ & P1 & $\mathbf{P 2}$ & P1 & $\mathbf{P 2}$ & P1 & $\mathbf{P 2}$ \\
\hline $\begin{array}{l}\text { 1.- Rubrics as Authentic Assessment } \\
\text { Tools Enhancing Writing and Speaking } \\
\text { Skills }\end{array}$ & 5 & 5 & 4 & 4 & 3 & 4 & 3 & 4 & 4 & 4 & 19 & 21 \\
\hline $\begin{array}{l}\text { 2.- Augmented Reality applied as a } \\
\text { learning strategy on ESL learners }\end{array}$ & 5 & 5 & 4 & 4 & 4 & 4 & 3 & 4 & 3 & 4 & 19 & 21 \\
\hline $\begin{array}{l}\text { 3.- Self-Assessment of Oral Skills using } \\
\text { Mobile Devices }\end{array}$ & 5 & 5 & 3 & 5 & 3 & 5 & 3 & 5 & 3 & 5 & 17 & 25 \\
\hline $\begin{array}{l}\text { 4.- Basic English enriched with } \\
\text { professional tasks improve professional } \\
\text { communication }\end{array}$ & 5 & 4 & 4 & 4 & 3 & 4 & 3 & 4 & 3 & 4 & 18 & 20 \\
\hline $\begin{array}{l}\text { 5.-Literature Circles Motivate English } \\
\text { Interaction in A1 University Students }\end{array}$ & 5 & 5 & 5 & 5 & 4 & 5 & 4 & 4 & 5 & 4 & 23 & 23 \\
\hline $\begin{array}{l}\text { 6.- Using Authentic Online Materials to } \\
\text { Improve B1 Level Listening } \\
\text { Proficiency }\end{array}$ & 5 & 4 & 4 & 4 & 3 & 2 & 4 & 3 & 4 & 3 & 20 & 16 \\
\hline $\begin{array}{l}\text { 7.- Graphic organizers as cognitive } \\
\text { strategies to promote independent EFL } \\
\text { learners }\end{array}$ & 5 & 5 & 4 & 5 & 2 & 4 & 2 & 4 & 3 & 4 & 16 & 22 \\
\hline $\begin{array}{l}\text { 8.- Implementing Performance-Based } \\
\text { Tasks as Summative Evaluations in EFL } \\
\text { Classrooms }\end{array}$ & 5 & 4 & 5 & 4 & 4 & 4 & 4 & 4 & 4 & 4 & 22 & 20 \\
\hline $\begin{array}{l}\text { 9.- Trailers In Facebook: An Authentic } \\
\text { Material To Motivate EFL Learning. }\end{array}$ & 5 & 2 & 4 & 2 & 3 & 2 & 2 & 1 & 2 & 2 & 16 & 9 \\
\hline $\begin{array}{l}\text { 10.- Closing Comprehension Gaps } \\
\text { Using Literature Circles: From Classics } \\
\text { to Blockbusters }\end{array}$ & 5 & 5 & 3 & 5 & 3 & 5 & 3 & 5 & 3 & 4 & 17 & 24 \\
\hline $\begin{array}{l}\text { 11.- Professional Tasks Enrich Basic } \\
\text { English for University Students }\end{array}$ & 5 & 4 & 4 & 4 & 4 & 3 & 4 & 3 & 4 & 3 & 21 & 17 \\
\hline $\begin{array}{l}\text { 12.- Teaching through English: } \\
\text { documenting experiences and sharing. }\end{array}$ & 4 & & 3 & & 2 & & 2 & & 3 & & 14 & 0 \\
\hline 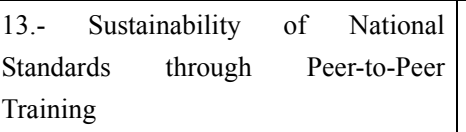 & 4 & $*$ & 4 & & 4 & & 4 & & 4 & & 20 & 0 \\
\hline AVERAGE INDICATOR & 4,85 & 4,36 & 3,92 & 4,18 & 3,23 & 3,81 & 3,15 & 3,72 & 3,46 & 3,72 & 18,6 & 19,8 \\
\hline POSITION OF CRITERION & 1 & 1 & 2 & 2 & 4 & 3 & 5 & 4 & 3 & 4 & & \\
\hline
\end{tabular}




\section{Appendix F}

Results of Coding Scheme

\begin{tabular}{|c|c|c|c|c|c|c|c|c|c|c|c|}
\hline PROPOSALS & $\begin{array}{l}\text { Territory } \\
\text { (context) }\end{array}$ & \begin{tabular}{|l} 
Reporting \\
previous \\
research \\
(RPR)
\end{tabular} & Gap & Goal & Means 1 & Means 2 & Outcomes & Benefits & $\begin{array}{l}\text { Importance } \\
\text { claim }\end{array}$ & $\begin{array}{l}\text { Competence } \\
\text { claim }\end{array}$ & $\begin{array}{l}\text { Number } \\
\text { of moves }\end{array}$ \\
\hline 1 & $\checkmark$ & $\mathrm{x}$ & $\checkmark$ & $\checkmark$ & $\mathrm{x}$ & $\mathrm{x}$ & $\checkmark$ & $\checkmark$ & $\checkmark$ & $\mathrm{x}$ & 6 \\
\hline 2 & $\mathrm{X}$ & $\checkmark$ & $\checkmark$ & $\checkmark$ & $\checkmark$ & $\mathrm{X}$ & $\mathrm{X}$ & $\checkmark$ & $\checkmark$ & $\mathrm{X}$ & 6 \\
\hline 3 & $\checkmark$ & $\checkmark$ & $\checkmark$ & $\checkmark$ & $\checkmark$ & $\mathrm{x}$ & $\checkmark$ & $\checkmark$ & $\checkmark$ & $\checkmark$ & 9 \\
\hline 4 & $\checkmark$ & $\checkmark$ & $\checkmark$ & $\checkmark$ & $\checkmark$ & $\mathrm{X}$ & $\checkmark$ & l & $\checkmark$ & $\mathrm{X}$ & 8 \\
\hline 5 & $\checkmark$ & $\checkmark$ & $\mathrm{X}$ & $\checkmark$ & $\checkmark$ & $\checkmark$ & $\checkmark$ & $\checkmark$ & $\checkmark$ & $\mathrm{X}$ & 8 \\
\hline 6 & $\checkmark$ & $\checkmark$ & $\checkmark$ & $\checkmark$ & $\checkmark$ & $\checkmark$ & $\checkmark$ & $\checkmark$ & $\checkmark$ & $\checkmark$ & 10 \\
\hline 7 & $X$ & $\checkmark$ & $\checkmark$ & $\checkmark$ & $X$ & $\checkmark$ & $\checkmark$ & s & $\checkmark$ & $\checkmark$ & 8 \\
\hline 8 & $\mathrm{X}$ & $\sigma$ & $\checkmark$ & $\sigma$ & $\mathrm{X}$ & $\checkmark$ & $\checkmark$ & $\checkmark$ & $\checkmark$ & $\checkmark$ & 8 \\
\hline 9 & X & $X$ & $\checkmark$ & $\checkmark$ & $\checkmark$ & $\checkmark$ & $\checkmark$ & $\checkmark$ & $\checkmark$ & $\mathrm{X}$ & 7 \\
\hline 10 & $\checkmark$ & $\checkmark$ & $\checkmark$ & $\checkmark$ & $\mathrm{X}$ & $\checkmark$ & $\checkmark$ & $\checkmark$ & $\checkmark$ & $\checkmark$ & 9 \\
\hline 11 & $\checkmark$ & $\mathrm{X}$ & $\checkmark$ & $\checkmark$ & $\checkmark$ & $\sigma$ & $\checkmark$ & s & $\checkmark$ & $\checkmark$ & 9 \\
\hline 12 & $X$ & $\mathrm{X}$ & $\checkmark$ & $\checkmark$ & $X$ & $\mathrm{X}$ & $\checkmark$ & $\checkmark$ & $\checkmark$ & $\mathrm{X}$ & 5 \\
\hline 13 & $\checkmark$ & $\mathrm{X}$ & $\checkmark$ & $\checkmark$ & $\mathrm{X}$ & $\mathrm{X}$ & $\mathrm{X}$ & $\checkmark$ & $\checkmark$ & $\mathrm{X}$ & 5 \\
\hline
\end{tabular}

\section{Copyrights}

Copyright for this article is retained by the author(s), with first publication rights granted to the journal.

This is an open-access article distributed under the terms and conditions of the Creative Commons Attribution license (http://creativecommons.org/licenses/by/4.0/). 